\title{
Applications of Microprobe Analysis in Pulmonary Pathology
}

\author{
Thomas A. Sporn \\ Department of Pathology, Duke University Medical Center, Durham NC 27710
}

Numerous clinical problems are addressed in the practice of diagnostic pulmonary pathology using investigation by means of analytic electron microscopy. The most frequent and useful application is in the identification and quantification of inorganic particulate matter within the lung. Such identification results in many cases in clinical decisions regarding potentials for exposure and means of therapy. In the medicolegal arena, agents responsible for the creation of pulmonary disease states may be identified, quantified, or exhonerated as responsible for disease etiology. This presentation will review the more common applications of analytic electron microscopy within diagnostic pulmonary pathology.

Several analytic techniques have been used in the identification of asbestos fibers and quantification of mineral content in lung tissue using x-ray diffractometry, infrared spectroscopy and phase contrast microscopy to name but a few. Our laboratory conducts such analyses using scanning electron microscopy (SEM). The superior resolution of SEM permits detection of fibers as small as 0.3 microns at magnifications of 10,000 to 20,000x, and may be coupled with energy dispersive x-ray analysis ( EDXA) to determine the chemical composition of asbestos and non-asbestos mineral fibers.

A particularly useful application of SEM/EDXA lies in the detection of beryllium, a mineral which may prduce granulomatous inflammation clinically and histologically indistinguishable from sarcoidosis. Our laboratory has been able to detect beryllium in human tissue samples using SEM equipped with a Robinson backscatter electron image detector. Other applications for SEM and backscatter electron imaging in our lab include diagnostic evaluations of hard metal lung disease, pulmonary sarcoidosis and the detection of organic material to support the diagnosis of granulomatous disease in the lung resulting from parenteral abuse of narcotic preparations intended for oral usage.

Selected References:

1. Sporn TA, Roggli VL et al. Overview of Applications Ch 3 In Biomedical Applications of Microprobe Analysis (Ingram P, Shelburne J, Roggli V, Lefurgey A, eds) Academic Press San Diego 1999

2. Butnor KL, Sporn TA, Ingram PI et al. Beryllium detection in human lung tissue using electron probe X-ray microanalysis Mod Pathol 200316 (11) 1171-1177

3. Roggli VL, Sharma A Analysis of Tissue Mineral Content, Ch 11 In Pathology of Asbestos Associated Diseases ( Roggli VL, Oury TD, Sporn TA,eds) Springer Verlag, New York $2^{\text {nd }}$ edition 2004

4. Roggli VL, Sharma A, Butnor KJ, Sporn T, Vollmer RT Malignant mesothelioma and occupational exposure to asbestos: A clinicopathologic correlation of 1445 cases. Ultrastruct Pathol2002 26: 55-65 
